\title{
PRINCÍPIO DA PROTEÇÃO DA CONFIANÇA - FUNDAMENTOS PARA LIMITAÇÃO DOS PODERES CONSTITUÍDOS NA MODIFICAÇÃO DE DIREITOS SOCIAIS EM TEMPO DE CRISE
}

\author{
PRINCIPLE OF THE PROTECTION OF TRUST - FOUNDATIONS FOR LIMITATION OF THE POLITICAL \\ POWERS CONSTITUTED IN THE MODIFICATION OF SOCIAL RIGHTS IN TIMES OF CRISIS
}

Leonardo David Quintiliano*

\begin{abstract}
Resumo:
O presente artigo analisa a construção jurisprudencial e doutrinária do princípio da proteção da confiança, bem como seu desenvolvimento em Portugal como limitação à atuação dos poderes constituídos na modificação de leis concretizadoras de direitos sociais. A partir do pioneiro desenvolvimento, pelo Tribunal Constitucional português, de critérios para aplicação desse princípio aos casos concretos, especialmente na supressão ou redução de direitos sociais em tempos de crise, compara-se o recurso ao princípio pela jurisprudência constitucional brasileira.
\end{abstract}

Palavras-chave: Estado de Direito. Segurança Jurídica. Proteção da Confiança. Direitos Sociais.

\begin{abstract}
:
This paper analyzes the case law and legal scholarship construction of the principle of trust as well as its development in Portugal as a limitation to the action of the political constituted powers in relation to modification of social rights laws. Based on the pioneering development by the Portuguese Constitutional Court of criteria for the application of that principle to particular cases, especially in the suppression or reduction of social rights in times of crisis, its use by Brazilian constitutional case law is compared.
\end{abstract}

Keywords: Rule of Law. Legal Certainty Principle. Principle of Trust. Social Rights.

Introdução

O presente estudo analisa a construção jurisprudencial e doutrinária do princípio da segurança jurídica - especialmente de sua dimensão subjetiva, denominada pela doutrina de confiança, confiança legítima, ou proteção da confiança, bem como sua utilização no Brasil e em Portugal como limitação da atuação dos poderes constituídos

Doutor em Direito Constitucional pela Universidade de São Paulo. Mestrando em Ciências JurídicoPolíticas pela Universidade de Lisboa. Professor Doutor de Direito Constitucional e Administrativo da Universidade Ibirapuera. 
e até mesmo do poder constituinte derivado na modificação de leis concretizadoras de direitos sociais. ${ }^{1}$

Estado de Direito é um conceito vago, cuja densificação axiológica e normativa é construída com o auxílio de ciências afins. No plano jurídico e sociológico, a expressão aparece como ideia-força, donde emergem formulações teóricas que pretendem conferir normatividade a valores morais e ideológicos, deduzidos a partir da précompreensão do referido princípio.

Uma dessas formulações propõe extrair da segurança jurídica, pressuposto de criação e subsistência desse Estado de Direito, valores que irradiam efeitos normativos suscetíveis de per si limitarem a atuação da função legislativa, dentre os quais se encontra a proteção da confiança, uma espécie de segurança jurídica subjetiva.

Diversamente de outros princípios igualmente extraídos da concepção de Estado de Direito, como o próprio princípio da segurança jurídica, que se encontra implicitamente previsto na Constituição Federal de $1988,{ }^{2}$ não há uma previsão constitucional expressa do princípio da proteção da confiança, pelo que a ideia de sua aplicação prima facie soaria como uma hipótese de ativismo judicial, ou mesmo de uma manifestação neoconstitucional em sentido amplo.

Não obstante, muitos tribunais europeus, ${ }^{3}$ já há cerca de três décadas, têm aplicado o princípio da confiança para limitar a atuação do legislador na modificação de leis concretizadoras de direitos sociais. No Brasil, a aplicação do princípio é mais tímida e recente, mas já aparece em alguns julgados, incluindo-se decisões do Supremo Tribunal Federal.

\footnotetext{
Não interessa ao presente estudo, em razão do corte epistemológico ora proposto, as construções da segurança jurídica e proteção da confiança com base em metanarrativas jurídicas de caráter sociológico como as que se encontram em Luhman (1983, p. 109-123), no sentido de que o direito cumpre uma função estabilizadora das expectativas geradas numa sociedade complexa como condição de preservação de sua existência, ou mesmo da Teoria Geral do Direito, que se fundam na pré-compreensão de que a segurança jurídica é um princípio estruturante de - e, mesmo, inerente a - qualquer ordenamento jurídico. (GARCIA MANRIQUE, 2012, p. 337 e ss.).

2 Com efeito, dispõe o art. $5^{\circ}$ da Constituição Federal de 1988: "Todos são iguais perante a lei, sem distinção de qualquer natureza, garantindo-se aos brasileiros e aos estrangeiros residentes no País a inviolabilidade do direito à vida, à liberdade, à igualdade, à segurança e à propriedade, nos termos seguintes:”. (Grifo nosso). Também dispõe o art. 103-A, § 1º da Constituição Federal de 1988: "A súmula terá por objetivo a validade, a interpretação e a eficácia de normas determinadas, acerca das quais haja controvérsia atual entre órgãos judiciários ou entre esses e a administração pública que acarrete grave insegurança jurídica e relevante multiplicação de processos sobre questão idêntica". (Grifo nosso).

3 Além de Portugal, onde o princípio encontra-se bastante densificado e, por isso, será mais referido, citem-se a jurisprudência espanhola (confianza legitima), alemã (vertrauensschutz), holandesa (vertrouwensbeginsel), lituana (teisètu lūkesčiu - legitimate expectations), italiana (legittimo affidamento) suíça, francesa e o Tribunal de Justiça das Comunidades Europeias (attente legitime), dentre outras. (RODRÍGUEZ-ARANA, 2013, p. 66; SANZ RUBIALES, 2000, p. 95; CALMES, 2001, p. 117; PRANEVIČIENĖ; MIKALAUSKAITE்ŠOSTAKIENĖ, 2012, p. 643-656).
} 
Ao contrário do exemplo europeu, porém, em que o emprego à proteção da confiança se acentua em tempos de crise econômico-financeira, durante os quais o Estado tende a restringir ou a suprimir direitos sociais, no Brasil a jurisprudência passou a empregar o princípio durante períodos de grande crescimento econômico. Resta, portanto, saber, se ele será aplicado pelos tribunais brasileiros também nos momentos de recessão e crise política, especialmente a iniciada em 2014.

Nesse sentido, diante de mudanças reclamadas pelo momento de crise econômico-financeira, especialmente a reforma previdenciária, o princípio da proteção da confiança pode oferecer uma garantia complementar ao princípio do direito adquirido, especialmente em aspectos por este não alcançados, como se dá na hipótese de limitação ao Poder Constituinte derivado e à expectativa de direito ou, como é mais empregado em Portugal, a figura dos direitos em formação.

\section{A segurança jurídica como princípio implícito do Estado de Direito}

A expressão Estado de Direito refere-se ao Estado cujos poderes constituídos são limitados por normas emanadas do poder que os constitui e por normas que se pressupõem universalizáveis, por refletirem a proteção presumidamente desejada de todo ser humano à sua liberdade de autodeterminação, à preservação de sua integridade física e moral, à garantia de paz social e de previsibilidade e estabilidade das relações sociais e políticas, sendo tais normas, positivadas ou não, legitimadas democraticamente.

O termo Estado de Direito passa a ser utilizado por volta de $1800,{ }^{4}$ mas a ideia de um Estado que romperia com as concepções maquiavelianas que justificavam o Estado de Polícia tem início mais de 100 anos antes.

$4 \quad$ Jorge Reis Novais, e.g., afirma que o conceito foi desenvolvido por Von Mohl na obra "Die Polizeiwissenschaft nach den Grundsatzen des Rechtsstates" (Ciência policial de acordo com os princípios dos Estados de Direito), em 1832-3, mas o autor já a haveria empregado em debates políticos em 1829 (NOVAIS, 2006, p. 47). No mesmo sentido Lucas Verdú (1975, p. 21). Friedrich A. V. Hayek, por sua vez, noticia que a palavra Rechtsstaat teria aparecido pela primeira vez em K. T. Welcker, em sua obra "Die letzten Gründe von Recht, Staat und Strafe" (As razões últimas do Direito, Estado e Punição), publicada em 1813. O significado do termo ali empregado, porém, não corresponderia ao significado que lhe foi dado posteriormente, cujo movimento teórico apenas teria iniciado no fim do século XVIII, sob a influência de estudiosos ingleses (HAYEK, 1983, p. 239, nota 26). Manoel G. Ferreira Filho, em sua obra "Estado de direito e constituição" (1988, p. 5), filia-se à essa tese. Entretanto, em sua obra "Princípios fundamentais do direito constitucional" (2009, p. 176), o autor informa que Luc Heuschling atribui a Johann Wilhelm Placidus o pioneirismo no uso da expressão Rechtsstaat, a qual teria sido por ele empregada em 1798, na obra "Literatur der Staatslehre. Ein Versuch", para designar a Escola de Kant. No mesmo sentido, Sérgio Resende de Barros (2007, p. 138). Essa parece a tese mais plausível. Tal fato é confirmado por Gustavo Gozzi, segundo o qual Kant e seus alunos foram chamados de Escola Crítica ou Doutrina do Estado de Direito (Rechts-Staats-Lehrer) (GOZZI, 2011, p. 85). Também informam Sharon Byrd e Joachim Hruschka que Placidus era um pseudônimo usado por Petersen, a obra foi publicada em Stuttgart, não em Estrasburgo, mais provavelmente em 1797 (BYRD; HRUSCHKA, 2010, p. 27). 
O Estado de Polícia se caracterizava por decisões arbitrárias e imprevisíveis do Monarca. Os cidadãos e a própria burguesia, que antes se beneficiavam da segurança dada pelo Monarca, começam a se ressentir de uma menor intervenção estatal e buscar a substituição da ideologia cristã por um processo racional que vai exigir também maior racionalidade do Estado.

Essa exigência de previsibilidade - segurança jurídica - vai ser um dos elementos centrais para a superação desse Estado de Polícia, a qual encontrou eco na doutrina contratualista, que já traçava os contornos do Estado de Direito em suas obras. ${ }^{5}$ Mesmo tendo uma pretensão político-filosófica, podem ser encontrados em tais autores elementos jurídicos que serão considerados essenciais para o Estado de Direito. Luis Fleitas de León destaca tais elementos, a seguir indicados resumidamente: a ideia de que o Estado não é algo espontâneo, mas é fruto da vontade dos indivíduos; a consciência de que a soberania, como poder político coercitivo, pertence ao povo; a noção de que o Estado deve se organizar num sistema de separação das funções legislativa, executiva e jurisdicional; a limitação do poder dos governantes pela adoção de um sistema de freios e de contrapesos e pela submissão à lei; e a garantia dos direitos da pessoa humana (FLEITAS DE LÉON, 2011, p. 24).

Tais ideias influenciaram o conteúdo das primeiras Constituições e Declarações de Direitos, especialmente na França e nos Estados Unidos, as quais inspiraram o conteúdo das Constituições modernas. ${ }^{6}$ Dessas influências, é relevante destacar o art. 2. ${ }^{\circ}$ da Declaração de Direitos do Homem e do Cidadão de 1789:

Art. 2..$^{\circ}$ - Le but de toute association politique est la conservation des droits naturels et imprescriptibles de l'Homme. Ces droits sont la liberté, la propriété, la sûreté, et la résistance à l'oppression. ${ }^{7}$ (Grifo nosso).

Nascia, assim, o Estado de Direito, consagrando a segurança como um direito natural e imprescritivel do homem.

A partir dessas considerações históricas e de uma análise teleológica de sua criação, é possível atribuir, com algum consenso ao menos doutrinário e jurisprudencial, um conteúdo mínimo para o conceito de Estado de Direito, composto dos seguintes elementos: garantia de liberdade, igualdade e segurança, bem como dos demais direitos e

Dentre outros, Rousseau (1762); Locke (1689) e Montesquieu (1949).

6 Luis Fleitas de León faz uma análise dos documentos políticos referentes à independência das antigas 13 colônias que formariam os Estados Unidos da América, bem como da Declaração de Direitos do Homem e do Cidadão de 1789 (FLEITAS DE LÉON, 2011, p. 24-25).

7 "Artigo $2{ }^{\circ}$ - O fim de toda associação política é a conservação dos direitos naturais e imprescritíveis do homem. Esses direitos são a liberdade, a propriedade, a segurança e a resistência à opressão.”. (Traduzimos e destacamos em itálico o termo sûreté (segurança). 
liberdades considerados fundamentais, sujeição do poder ao direito e divisão dos poderes. Também é possível estabelecer o seguinte paralelo entre fins e meios:

\begin{tabular}{|l|l|}
\hline \multicolumn{1}{|c|}{ FINS (valores) } & MEIOS (princípios jurídicos) \\
\hline $\begin{array}{l}\text { Proteção do indivíduo contra o abuso do } \\
\text { poder }\end{array}$ & $\begin{array}{l}\text { Divisão dos poderes, legalidade, garantia } \\
\text { de direitos fundamentais inerentes a uma } \\
\text { dignidade mínima do ser humano }\end{array}$ \\
\hline $\begin{array}{l}\text { Igualdade de tratamento aos membros da } \\
\text { mesma coletividade, iguais por natureza }\end{array}$ & $\begin{array}{l}\text { Garantia de atos administrativos, } \\
\text { legislativos e jurisdicionais que observem } \\
\text { o princípio da igualdade }\end{array}$ \\
\hline $\begin{array}{l}\text { Proteção do indivíduo contra abusos de } \\
\text { membros da coletividade }\end{array}$ & \multicolumn{1}{|c|}{ Poder de polícia } \\
\hline $\begin{array}{l}\text { Previsibilidade e estabilidade dos negócios } \\
\text { jurídicos }\end{array}$ & Legalidade e segurança jurídica \\
\hline $\begin{array}{l}\text { Participação do indivíduo na formação da } \\
\text { vontade estatal }\end{array}$ & Regime democrático \\
\hline
\end{tabular}

O quadro acima sintetiza as concepções de um Estado pretendido pela sociedade, segundo os ideais das Revoluções que conformaram o constitucionalismo contemporâneo. Como se pode observar, a ideia de Estado de Direito encerra fins e meios, em uma articulação que lhe confere certa unidade sistemática. ${ }^{9}$

Tal concepção se legitima democraticamente na medida em que, como defende Peter Häberle, ${ }^{10}$ a primeira coluna contempla, com uma pequena margem de dissenso, os fins do Estado contemporâneo aceitos pela sociedade. Deveras, o cidadão médio das democracias contemporâneas talvez não saiba em que consiste exatamente a expressão Estado de Direito. Tampouco a expressão é empregada com pleno domínio

8 Embora alguns autores, como Zippelius, reconheçam a existência de um Estado de Direito não democrático, essa não seria a concepção no Brasil, pelas considerações anteriormente expostas. (ZIPPELIUS, 1997, p. 383-384).

9 Há muitos outros elementos presentes em outros autores, os quais não encontram consenso, como o reconhecimento de uma personalidade jurídica do Estado, a existência de um controle de constitucionalidade, bem como da responsabilidade do Estado e de seus agentes (CANOTILHO; MOREIRA, 2007, t. 1, p. 205). No mesmo sentido, (AMARAL, 2005, p. 178; NOVAIS, 2004, p. 261; VERDÚ, 1975, p. 23-24; ZIPPELIUS, 1997, p. 392-393; OTERO, 2009, p. 532; MORAIS, 2000, p. 622; Idem, 2014, p. 479; KELSEN, 1999 , p. 218).

10 Segundo Häberle, o caráter dinâmico da realidade que empresta significado ao texto normativo exige uma constante conformação da Constituição à realidade sobre a qual ela se projeta, o que só pode se dar se a interpretação da Constituição se legitimar democraticamente (HÄBERLE, 2002, p. 10 e ss.). 
de alguns de seus elementos constitutivos, ou seu conteúdo em determinado Estado é discutido pelas Assembleias Constituintes. Mas os elementos que a constituem, como os ideais de igualdade, estabilidade e liberdade estão presentes na concepção da maioria dos indivíduos, bem assim dos seus representantes constituintes. Podem ser consideradas, ao menos no seio das sociedades formadas sob os valores cristãos, verdades evidentes, pré-racionais, que dispensam uma persuasão política ou demonstração lógico-racional (COUTINHO, 2009, p. 210).

Essa constatação confere legitimidade à adoção de um conceito mínimo de Estado de Direito. Ínsito a essa concepção está, portanto, a segurança, não apenas enquanto mera proteção da integridade física, mas também como estabilidade da ordem jurídica. ${ }^{11}$ É o que se convencionou chamar de segurança jurídica.

Nesse sentido, como escreve Canotilho, o princípio do Estado de Direito, densificado pela segurança jurídica e pela confiança jurídica, reforça a coexistência de dois elementos: um objetivo da ordem jurídica, relacionada à sua durabilidade, paz jurídicosocial; outro garantístico e subjetivo, de proteção à confiança de permanência das situações jurídicas. (CANOTILHO, 2003, p. 259).

Kelsen, embora vendo um pleonasmo na expressão Estado de Direito, dada sua concepção monista entre Direito e Estado, ${ }^{12}$ reconhece o emprego da expressão composta para "designar um tipo especial de Estado, a saber, aquele que satisfaz aos requisitos da democracia e da segurança jurídica". (KELSEN, 1999, p. 218).

A segurança jurídica consistiria, no entanto, em um "princípio-pressuposto" do próprio Direito, destinado a garantir a "estabilidade, certeza e coerência normativas, bem como a calculabilidade dos comportamentos das instituições e dos cidadãos". (MORAIS, 2001, p. 14).

Na mesma linha, também o Supremo Tribunal Federal brasileiro e o Tribunal Constitucional de Portugal reconhecem que o princípio da segurança jurídica é elemento conceitual do Estado de Direito. ${ }^{13}$

11 Como escreve Paulo Mota Pinto (2014, p. 137), “a confiança está na base da própria 'possibilidade de vigência da ordem constitucional', uma vez que é a manutenção da confiança no ordenamento, e respeito às garantias e regras que prevê, que permite a continuidade da vigência da ordem constitucional".

12 Para Kelsen "se o Estado é reconhecido como uma ordem jurídica, se todo Estado é um Estado de Direito, esta expressão representa um pleonasmo” (KELSEN, 1999, p. 218).

13 Segundo o STF: "O Estado de direito é um estado de segurança jurídica. E a segurança exige que os cidadãos saibam com o que podem contar, sobretudo nas suas relações com os poderes públicos. Saber com o que se pode contar em relação aos atos da função legislativa do Estado é coisa incerta ou vaga, precisamente porque o que é conatural a essa função é a possibilidade, que detém o legislador, de rever ou alterar, de acordo com as diferentes exigências históricas, opções outrora tomadas. Contudo, a possibilidade de alteração dessas opções, se é irrestrita (uma vez cumpridas as demais normas constitucionais que sejam 
2. A segurança jurídica: conceito e dimensões

Se é possível dizer que o conceito de Estado de Direito permite inferir logicamente a noção de segurança jurídica, seu conteúdo e dimensões encontramse indeterminados, porém são determináveis em cada ordem jurídica, segundo as necessidades da sociedade subjacente.

Algumas dimensões são propostas pela doutrina, destacando-se quatro principais: o conhecimento (do direito), a confiança ou previsibilidade, a estabilidade e a coerência. $^{14}$

Jorge Miranda ainda acrescenta a compreensibilidade (clareza), a razoabilidade (como não arbitrariedade) e a determinabilidade (densificação do conteúdo normativo). (MIRANDA, 2012, p. 311-312).

\section{Carlos Blanco de Morais destaca também o}

imperativo de garantia da certeza da ordem jurídica, nas suas dimensões da estabilidade, coerência, e igualdade, permitindo aos cidadãos organizarem a sua vida individual e social no respeito pela previsibilidade e calculabilidade normativa de expectativas de comportamento e das consequências derivadas das respectivas ações (MORAIS, 2000, p. 621).

Humberto Ávila acresce ainda a confiabilidade no passado e calculabilidade das mudanças do futuro. (ÁVILA, 2011, p. 124-125).

O primeiro conteúdo, do conhecimento do direito, situa-se numa dimensão estática e refere-se à certeza de vigência das normas e de um mínimo conhecimento delas. O conhecimento do direito requer normas claras e com um conteúdo determinável, bem como uma coerência e uma consistência do ordenamento. (ÁVILA, 2011, p. 320).

Já a confiança ou previsibilidade, que evoca também a estabilidade, situa-se numa dimensão dinâmica e volta-se a ação do direito no tempo. Exige-se,

aplicáveis) quando as novas soluções legislativas são pensadas para valer apenas para o futuro, não pode deixar de ter limites sempre que o legislador decide que os efeitos das suas escolhas hão de ter, por alguma forma, certa repercussão sobre o passado". (BRASIL, 2007, p. 146). Já o Tribunal Constitucional de Portugal limita-se a seguir a jurisprudência do Tribunal Constitucional Federal Alemão: "Relevante é, porém, que aquele Tribunal tem entendido que também na chamada «retroactividade inautêntica» os princípios da segurança jurídica e da protecção da confiança, que integram o princípio do Estado de direito, impõem limites que o legislador tem de respeitar, considerando-se ofendida a protecção da confiança, sempre que a lei desvaloriza a posição do indivíduo de modo com que este não deva contar, que não tinha, portanto, que considerar ao dispor da sua vida”. (PORTUGAL, 1990).

14 Por todos, conferir Morais (2014, p. 482); Freitas (2006, p. 820); Ávila (2011, p. 122 e ss.); Miranda (2012, p. 311-312); Alexandrino (2007, p. 79); Rocha Júnior (2014, p. 146); Medauar (2005, p. 115); Stein (2000, p. 117); Novais (2004, p. 261). 
assim, intangibilidade de situações passadas, permanência do ordenamento jurídico e irretroatividade das normas presentes. (ÁVILA, 2011, p. 339 e ss.).

A segurança jurídica se projeta de diversas formas e atinge toda a atuação estatal: no exercício da função legislativa e da função administrativa, e.g., sob a forma de irretroatividade; no exercício da função jurisdicional, sob a forma de preservação da coisa julgada e vinculação a precedentes, dentre outros. (ÁVILA, 2011, p. 342 e ss.).

No direito processual, a segurança jurídica assume a forma da prescritibilidade. No direito substancial, atua por meio da decadência.

A segurança jurídica apresentaria, também, uma dimensão objetiva e uma dimensão subjetiva. A dimensão objetiva refletiria a busca da estabilidade do direito. Já a dimensão subjetiva refletiria as expectativas individuais quanto a essa estabilidade. (MORAIS, 2014, p. 482).

Vista, assim, sob a ótica subjetiva, a segurança jurídica decorreria da ideia, ínsita ao contrato social constitucional, ${ }^{15}$ de que a relação de confiança depositada no aparato governamental observa um aspecto de ultratividade constituinte, ou seja, a aceitação do ideário subjacente no momento pré-constituinte, de adesão aos fundamentos teóricos e características do Estado de Direito, projeta-se na atuação dos poderes constituídos e do Poder Constituinte derivado, vinculando-os.

\section{A dimensão subjetiva da segurança jurídica: a confiança}

Conquanto se registrem antecedentes até mesmo no Direito Canônico, datado de 896, e na própria jurisprudência francesa, em 1922 (ARAÚJO, 2009, p. 18), a doutrina costuma assentar a origem do recurso a essa dimensão subjetiva do princípio da segurança jurídica, denominada de princípio da proteção da confiança, princípio de proteção à confiança, princípio de proteção à confiança legítima ou apenas princípio da confiança, na jurisprudência alemã por volta da década de 1950. São utilizados dois acórdãos de tribunais administrativos alemães datados de 1956 e 1957 como os primeiros

15 Emprega-se a expressão contrato social constitucional, como uma fusão das ideias de contrato social, conhecida e empregada pelos contratualistas, com a ideia de poder constituinte. Quer-se referir não apenas à vontade constituinte, formalmente manifestada por meio do processo constituinte, mas também à concepção contratualista de sociedade, que justificaria, para um cidadão com uma consciência política média, sua convivência em sociedade e as regras do jogo que levam à sua conformação constitucional. Isso, no entanto, não quer dizer que se concorde com a ideia de que a Constituição é um mero contrato de natureza política. Pelo contrário, uma análise dialética do fenômeno constitucional demonstra que se trata mais de uma imposição de normas por grupos dominantes na sociedade. Nesse sentido, Carlos Blanco de Morais entende a imposição da vontade dos "mais" sobre os "menos". Esse "mais", no entanto, não representa necessariamente uma maioria quantitativa, mas uma maioria qualitativa, que consegue, mediante o emprego do poder político ou econômico, atingir tal maioria numérica para fazer prevalecer sua vontade, pelo uso de recursos ideológicos (MORAIS, 2014, p. 423). 
a empregarem tal princípio, mas para a questão da boa-fé na percepção de vantagens econômicas decorrentes de erro de fato no cálculo. ${ }^{16}$ A partir de então, o princípio teve seu uso alargado para alcançar todas as formas de atuação do Estado que afetassem as expectativas dos indivíduos. Tal como se deu com a construção do princípio da proibição do retrocesso, também o princípio da proteção da confiança nasce de casos concretos mais afetos a questões patrimoniais - mediante o emprego de um processo indutivo - que de um processo dedutivo a partir de uma teoria dos direitos fundamentais (DERBLI, 2008, p. 345).

Segundo Jorge Miranda e Rui Medeiros, trata-se de uma norma-princípio, de gestação essencialmente jurisprudencial, com raiz no princípio do Estado de Direito, que determina que as autoridades públicas não devem contrariar ou afetar com os seus atos as expectativas legítimas dos particulares, a não ser que um interesse de peso superior justifique essa afetação. (MIRANDA; MEDEIROS, 2010, p. 213-241).

A mesma tese é adotada pelo Tribunal Constitucional de Portugal, que reconhece a confiança como "uma norma com natureza principiológica que deflui de um dos elementos materiais justificadores e imanentes do Estado de Direito: a segurança jurídica”. (PORTUGAL, 2013b).

A doutrina apresenta grande dissenso acerca do conteúdo, ou mesmo do emprego de tal princípio, dada sua construção abstrata e sua limitação da discricionariedade legislativa. (ALEXANDRINO, 2014, p. 66).

Jorge Miranda, v.g., descreve a proteção da confiança como a vinculação do Estado a um dever de boa-fé, de lealdade e de respeito aos particulares. (MIRANDA, 2012, p. 312).

Humberto Ávila enuncia quatro pressupostos do princípio da proteção da confiança, a saber: a) uma base de confiança do sujeito; b) a confiança nessa base; c) o exercício da liberdade, com base nessa confiança; d) frustração da confiança, por ato posterior e contraditório do Poder Público. (ÁVILA, 2011, p. 367).

Além da tese de que o princípio decorreria do Estado de Direito, a doutrina apresenta outros fundamentos para justificar o princípio.

Para Jorge Reis Novais, os particulares têm o direito de prever as atuações estatais e de não terem suas "legítimas" expectativas frustradas, especialmente por atos estatais "radicais". A delimitação do princípio se dá pela aplicação do critério da proporcionalidade, tendo como pressuposto a legitimidade, não admitindo as posições sustentadas em "ilegalidades" e "omissões". (NOVAIS, 2004, p. 263).

$\overline{16}$ Sobre o caso e seus fundamentos, cf. Maurer (2001, p. 70). 
Jose de Melo Alexandrino enxerga na proteção da confiança uma ligação com: subordinação ao Estado de Direito; previsibilidade da atuação estatal; clareza e precisão das regras jurídicas; publicidade e transparência dos atos e dos procedimentos públicos; e respeito pelos direitos, expectativas e interesses legítimos dignos de proteção pelo direito. (ALEXANDRINO, 2007, p. 85).

Para Cristina Queiroz, o princípio comportaria uma leitura que decorre do princípio geral das obrigações de que os pactos devem ser cumpridos. (QUEIROZ, 2014, p. 25).

Toda essa construção teórica, porém, assenta-se em um plano axiológico. Se é verdade que da concepção de Estado de Direito é possível inferir um princípio da segurança jurídica, não é possível universalizar, de forma democraticamente legítima, um conteúdo para tal princípio. Prova disso é a diversidade, no direito comparado, de formas como as Constituições e os tribunais constitucionais e ordinários lidam com a questão da segurança jurídica, mediante a adoção ou não de proteção à retroatividade das leis, ao direito adquirido, aos direitos em formação, à coisa julgada, dentre outras.

Por tal razão, as manifestações doutrinárias que pretendem a adoção de um conteúdo universal para tal princípio, mormente a partir de pré-compreensões igualmente assentadas em valores, como o Estado de Direito e a dignidade da pessoa humana, esbarram no problema de legitimidade democrática para tal construção, representando não uma posição impessoal, mas uma imposição pessoal. ${ }^{17}$

Isso não quer dizer, porém, que, em face de um determinado ordenamento, não seja possível aferir um conteúdo maior ou menor de tal princípio. No entanto, essa constatação deverá ser feita diante de cada ordem jurídica, especialmente a partir da sua densificação no direito positivado e o cotejamento sistemático com os demais princípios a ele incorporados.

Sem embargo, dado o alto grau de desenvolvimento jurisprudencial e doutrinário na aplicação do princípio da proteção da confiança em Portugal, convém analisar os critérios de densificação do princípio ali propostos, com a finalidade de confrontá-los com sua aplicação no direito brasileiro, comparação que pode servir de referência para a construção de critérios próprios, mais afeiçoados ao ordenamento jurídico-constitucional brasileiro.

\section{A proteção da confiança em Portugal}

A Constituição da República Portuguesa - CRP não adota o princípio da irretroatividade absoluta das leis, mas apenas prevê a irretroatividade penal (art. 29, n. 4),

17 Dentre esses autores, cita-se: Sarlet (2008, p. 21-22). 
fiscal (art. 103, n. 3) e irretroatividade das leis restritivas de direitos, liberdades e garantias (art. 18, n. 3).

Por sua vez, o art. 17. prevê que o regime dos direitos, liberdades e garantias aplica-se aos direitos, liberdades e garantias pessoais, de participação política e dos trabalhadores e aos direitos de natureza análoga.

Diante dessa disposição, questiona-se se os "demais" direitos sociais na CRP seriam alcançados pelo princípio de irretroatividade previsto no art. 18, n. 3 .

Além disso, o referido dispositivo apenas trata dos casos de retroatividade autêntica, a qual atinge efeitos pretéritos de fatos pretéritos, desconsiderando as hipóteses de retroatividade inautêntica, que atinge os efeitos pendentes ou futuros de fatos passados.

Com efeito, alguns dos direitos sociais, no entanto, tais como os direitos à pensão, apresentam um aspecto intertemporal, destacando-se dois deles - a existência de efeitos pendentes de fatos passados, bem como a existência de direitos em formação.

Assim, poderia o legislador português, por exemplo, alterar a idade exigida para aposentadoria um dia antes de o funcionário público se aposentar, ou mesmo reduzir o valor das pensões? A resposta para questões como essa, tanto no ordenamento jurídico português, como no brasileiro, envolve uma análise prévia da construção do princípio da proteção da confiança em ambos os sistemas.

Em Portugal, a proteção da confiança foi inicialmente assimilada pela doutrina.

Alberto Xavier, em sua obra Manual de direito fiscal (1974, p. 191), já escrevia que a irretroatividade das leis fiscais, ainda que não expressa em lei, decorreria do próprio princípio da legalidade, o qual devia ser interpretado à luz da segurança jurídica e da proteção da confiança.

Canotilho, embora já fizesse referência à impossibilidade de leis retroativas, quando estas violassem outras normas constitucionais, veio a mencionar a proteção da confiança, como um desses princípios, na obra Direito constitucional II, v. 2, de 1981 (PORTUGAL, 1983b).

Essa doutrina inspirou a Comissão Constitucional, ${ }^{18}$ a qual, especialmente com o Acórdão n. 437, de 26 de janeiro de 1982, considerou "inconstitucional a norma retroactiva que viola de forma intolerável a segurança jurídica e a confiança que as pessoas e a comunidade têm a obrigação (e também o direito) de depositar na ordem jurídica que as rege" (PORTUGAL, 1983b).

\footnotetext{
18 A Comissão Constitucional tinha, dentre outras, a função de exercer o controle de constitucionalidade das leis e foi precursora do atual Tribunal Constitucional, criado em 1982, com a primeira revisão constitucional portuguesa.
} 
O Tribunal Constitucional seguiu a mesma linha, adotando o critério da segurança jurídica e da proteção da confiança para controle da constitucionalidade de leis retroativas:

Será dispensável enunciar agora, ainda que resumidamente, todos os elementos que caracterizam um Estado de Direito Democrático. Mas é indiscutível que entre tais elementos se contém o da proteç̧ão da confiança dos cidadãos face à actuação do Estado: é decerto uma exigência jurídica fundamental a de que o Estado não actue por forma a pôr em crise os direitos e as expectativas que os cidadãos legitimamente constituíram à sombra da ordem jurídica vigente - o Estado não deve agir de forma a trair a confiança dos cidadãos. (PORTUGAL, 1983a).

Alguns anos mais tarde, em 1990, o Tribunal Constitucional viria a desenvolver o conteúdo desse princípio da proteção da confiança. Em primeiro lugar, o conteúdo do princípio protegeria as expectativas legítimas contrariamente a qualquer ato estatal considerado inadmissível, arbitrário, ou demasiado oneroso, nas situações de retrospectividade (PORTUGAL, 1990).

Em uma argumentação confusa, o Tribunal Constitucional, primeiro, tenta densificar isoladamente o critério da inadmissibilidade, mediante estes dois critérios:

a) a afectação de expectativas, em sentido desfavorável, será inadmissivel, quando constitua uma mutação da ordem jurídica com que, razoavelmente, os destinatários das normas dela constantes não possam contar; e ainda

b) quando não for ditada pela necessidade de salvaguardar direitos ou interesses constitucionalmente protegidos que devam considerar-se prevalecentes (deve recorrer-se, aqui, ao princípio da proporcionalidade, explicitamente consagrado, a propósito dos direitos, liberdades e garantias, no n. 2 do artigo $18 .^{\circ}$ da Constituição). (Ibidem - Grifo nosso).

Em sua fundamentação, o Tribunal Constitucional associa o item "a" à ideia de onerosidade extraordinária e o item "b" à ideia de "onerosidade excessiva, inadmissível ou intolerável, porque injustificada ou arbitrária", afirmando, ainda, que tais critérios devem se complementar.

Finalmente, a arbitrariedade da medida e o excesso da frustração das expectativas são aferidas mediante a ponderação entre o interesse do legislador (interesse coletivo) na mudança da ordem jurídica e o interesse individual na manutenção da ordem jurídica.

Tratou-se de uma fusão de um critério já expresso na Constituição portuguesa (o da proporcionalidade) com outro critério de difícil controle apolítico, como 
o da previsibilidade subjetiva razoável dos destinatários da norma. Também é bom destacar que o critério da proporcionalidade não é somente o previsto no citado n. 2 do art. 18. da CRP, pois no parágrafo 28 do acórdão, o Tribunal Constitucional menciona a necessidade de ponderar interesses coletivos e interesses individuais (PORTUGAL, 1990).

Ou seja, pelo critério da proporcionalidade, o Tribunal Constitucional se coloca como árbitro da disputa entre a coletividade, representada pela Administração Pública e Poder Legislativo, e os particulares.

Em jurisprudência posterior, quase duas décadas depois, a pretexto de desenvolver a fórmula anterior, o Tribunal Constitucional apresenta novo critério para a densificação do princípio. Segundo tal critério, viola-se a proteção da confiança quando:

1. ${ }^{\circ}$ o Estado (mormente o legislador) tenha encetado comportamentos capazes de gerar nos privados «expectativas» de continuidade;

2. ${ }^{\circ}$ devem tais expectativas ser legítimas, justificadas e fundadas em boas razões;

$3 .^{\circ}$ devem os privados ter feito planos de vida tendo em conta a perspectiva de continuidade do «comportamento» estadual;

$4 .^{\circ}$ não ocorram razões de interesse público que justifiquem, em ponderação, a não continuidade do comportamento que gerou a situação de expectativa. ${ }^{19}$

Cumpre frisar que a relatora do citado acórdão, Maria Lúcia Amaral, simplesmente adotou em seu relatório sua própria tese, já explicitada em sua obra "A Forma da República”, publicada dois anos antes de sua eleição para o Tribunal:

Para que haja, em determinadas situações concretas, lesão do princípio da confiança - que tem a sua sedes materiae no artigo 2. ${ }^{\circ}$ da Constituição — é necessário que se perfaçam sempre quatro pressupostos essenciais:

1. ${ }^{\circ}$, que o Estado (os poderes públicos) tenham efectivamente tomado decisões, ou encetado comportamentos, susceptíveis de gerar nos cidadãos expectativas de continuidade;

$2 .^{\circ}$, que os cidadãos tenham eles próprios tomado decisões

— ou feito planos de vida — com fundamento nessas mesmas expectativas;

$3 .^{\circ}$, que tais expectativas na continuidade da política estadual sejam legítimas, porque fundadas, ou justificadas, por boas razões;

$4 .^{\circ}$, que a mudança do comportamento dos poderes públicos não seja exigida por um interesse público que,

19 Cf. Acórdão n. 128/2009 do Tribunal Constitucional (PORTUGAL, 2007). Foram efetuadas adaptações de pontuação no texto. 
pela sua importância e valor, sobreleve o valor da tutela das expectativas privadas. (AMARAL, 2005, p. 183).

$\mathrm{Na}$ mesma obra, a autora enfatiza que tais quatro critérios são sua interpretação da jurisprudência: “(...) Note-se, no entanto, que os "quatro pressupostos" que vêm enunciados no texto não se encontram assim mesmo fixados pela jurisprudência constitucional. Eles “interpretam" a jurisprudência; não a reproduzem”. (AMARAL, 2005, p. 183, nt. 202).

Os mesmos critérios foram seguidos nos acórdãos seguintes. ${ }^{20}$

O acórdão n. 862/2013, por sua vez, vai exigir outro critério: o do gradualismo da medida:

No juízo de ponderação que é imposto pela proteção da confiança, onde se confronta e valora a condição de pensionista, em princípio, sem possibilidade ou impossibilidade de regressar a uma vida ativa que permita recuperar o que lhe é retirado, com os referidos interesses públicos, que podem ser satisfeitos no horizonte mais alargado, a solução justa à luz do princípio da proporcionalidade imporia também que a implementação da medida se fizesse de forma gradual e diferida no tempo. Aplicá-la de uma só vez, seria ultrapassar, de forma excessiva, a medida de sacrifício que a natureza do direito à pensão poderá admitir. ${ }^{21}$

Assim, o Tribunal inscreve novo critério para aferição da observância da confiança legítima, que está ligada ao critério da necessidade.

Finalmente, o acórdão n. 575/2014 vai desenvolver o critério da confiança objetiva, que se aplica aos sistemas intergeracionais, como se dá no caso das pensões. Tal critério trata, na verdade, de uma frustração da confiança na estabilidade futura da ordem jurídica, que pode ser provocada nos mais jovens pelo ato estatal dirigido às pessoas mais velhas. Segundo o referido acórdão:

No domínio de um sistema previdencial como o nosso, que, como vimos, se financia (artigo $90 .^{\circ}$ da Lei de Bases da Segurança Social), quanto a prestações substitutivas dos rendimentos do trabalho, através de 'quotizações dos trabalhadores' e de 'contribuições das entidades patronais, a confiança, para além da dimensão estritamente subjetiva com que até agora foi tratada, adquire ainda uma dimensão objetiva, que se associa à sua própria legitimidade enquanto

\footnotetext{
20 Cf. Acórdãos do Tribunal Constitucional de Portugal ns. 3/2010, 396/2011 e 187/2013.

21 Cf. Acórdão n. 862/2013, considerando 44, (PORTUGAL, 2013b). Acórdão n. 862/2013, considerando 44. (itálico no original)
} 
sistema que implica um contrato entre gerações. Se para as presentes gerações da população ativa portuguesa - as que financiam o sistema previdencial através das suas quotizações - a frustração da confiança das gerações mais velhas, beneficiárias atuais do sistema que financiam, puder aparecer como questão constitucionalmente neutra, indiferente ou irrelevante, nenhuma razão terão elas próprias (as gerações presentes de contribuintes) para confiar na subsistência do modelo para o qual contribuem. ${ }^{22}$

Trata-se de um novo requisito, que vai integrar o primeiro critério, sobre a existência de expectativas dos cidadãos. Para o Tribunal Constitucional português, portanto, não apenas as expectativas individuais, subjetivas, devem ser tuteladas, mas também uma expectativa presumida, expressão que deveria ter sido empregada para que não haja uma aparente contradição com o termo confiança, que representa a face subjetiva da segurança jurídica.

\section{A proteção da confiança no Brasil}

No Brasil, o art. $5^{\circ}$ da Constituição Federal de 1988, em sua redação original, prevê em seu “caput” o direito à segurança. Não fala em segurança jurídica.

A doutrina extrai daí o entendimento de que o comando constitucional não obstante a polissemia do termo - adotou um conceito amplo de segurança. (ÁVILA, 2011, p. 33).

Mesmo autores que se debruçaram exaustivamente sobre o tema da segurança jurídica no Brasil, como Humberto Ávila, desconsideram os debates parlamentares na aferição do tema. Apreendem um sentido universal para o conceito a partir da doutrina estrangeira e mesmo dos debates romanos, mas não dedicam nenhuma nota a "mens legislatoris" (Ibid., p. 34 e ss.). ${ }^{23}$

22 Cf. Acórdão n. 575/2014 (PORTUGAL, 2014), considerando 22. (Grifo nosso).

23 De fato, a menção ao termo segurança apareceu diversas vezes na Assembleia Constituinte de 1988. Quando usado de forma isolada, o termo quase sempre era empregado para se referir à segurança não jurídica, à segurança pública, ou à segurança de Estado. Na Comissão de Sistematização, v.g., o Constituinte José Mendonça de Moraes adota a concepção de segurança como segurança não jurídica: "A inviolabilidade da liberdade precisa ser manifesta, o que não está no texto, ainda. E a nossa segurança? Temos o direito, direito concernente à segurança, à segurança do ser humano". Por vezes, aparece o termo "segurança do Estado" Anais da Assembleia Nacional Constituinte. Atas de Comissões. p. 207. Disponível em: $<$ http:// www.senado.gov.br/publicacoes/anais/constituinte/sistema.pdf>. Acesso em: 15 mar. 2015. Cf., dentre outras passagens, a menção do Constituinte constitucionalista Afonso Arinos no Suplemento "b", p. 3, e do Constituinte Sepúlveda Pertence, que depois viria a se tornar Ministro do STF, nos Anais da Subcomissão de Garantia da Constituição, Reforma e Emendas, p. 65; e a intervenção do Ministro do STF Sydnei Sanches, ao defender a vitaliciedade dos Ministros do STF como garantia da segurança jurídica nacional. Ibid., p. 225. 
O fato é que, a despeito do "malabarismo" teórico para justificar que a concepção de segurança prevista no art. $5^{\circ}$ decorre de uma construção histórica e comparada, o termo segurança jurídica aparece no Anteprojeto da Subcomissão dos Direitos e Garantias Individuais, designando o inciso V, que viria a corresponder ao inciso XXXVI do art. $5^{\circ}$. Segundo o Anteprojeto:

Art. (...) São direitos e garantias individuais:

$\mathrm{V}$ - A segurança jurídica. A lei não prejudicará o direito adquirido, o ato jurídico perfeito e a coisa julgada e não poderá excluir da apreciação do Poder Judiciário nenhuma lesão de direito (BRASIL, Anais da Assembleia Nacional Constituinte, p. 207 e 285). (Grifo nosso).

Posteriormente, pela Emenda Constitucional n. 45/2004, o Poder Constituinte derivado acabou, implicitamente, revelando a segurança jurídica como princípio constitucional, embora não possa daí se inferir uma dedução do princípio, pelo legislador constituinte, seja a partir da ideia de Estado de Direito, ou do princípio da segurança jurídica consagrado no art. $5^{\circ}$ :

Art. 103-A. O Supremo Tribunal Federal poderá, de ofício ou por provocação, mediante decisão de dois terços dos seus membros, após reiteradas decisões sobre matéria constitucional, aprovar súmula que, a partir de sua publicação na imprensa oficial, terá efeito vinculante em relação aos demais órgãos do Poder Judiciário e à administração pública direta e indireta, nas esferas federal, estadual e municipal, bem como proceder à sua revisão ou cancelamento, na forma estabelecida em lei. (Incluído pela Emenda Constitucional n. 45, de 2004).

$\S 1^{\circ}$ A súmula terá por objetivo a validade, a interpretação e a eficácia de normas determinadas, acerca das quais haja controvérsia atual entre órgãos judiciários ou entre esses e a administração pública que acarrete grave insegurança jurídica e relevante multiplicação de processos sobre questão idêntica. (Grifo nosso).

Assim, pode-se afirmar que na Constituição de 1988, a par dessa previsão isolada e indireta no parágrafo primeiro do art. 103-A, a segurança jurídica encontrase genericamente contemplada no art. $5^{\circ}$, XXXVI. Sem embargo, outros dispositivos constitucionais a garantem, sob a forma de irretroatividade penal ou fiscal. ${ }^{24}$ Daí com razão Humberto Ávila ao afirmar que o princípio da segurança jurídica no direito

${ }_{24}$ Cf. art. 50, XL e art. 150, I e III, "a" e "b", da CF-88. 
brasileiro é dedutível a partir do princípio do Estado de Direito e indutível a partir de regras constitucionais da proteção ao direito adquirido, do ato jurídico perfeito e da coisa julgada, como a regra legalidade, anterioridade e irretroatividade. (ÁVILA, 2005, p. 247).

Além desses dispositivos, a Constituição de 1988 não consagra, a exemplo da Constituição portuguesa, o princípio da irretroatividade absoluta. Não obstante, a proteção constitucional ao direito adquirido e ao ato jurídico perfeito acaba por reduzir a necessidade de aplicação do princípio da segurança jurídica e suas variantes, como a confiança jurídica.

No entanto, assim como em Portugal o recurso à proteção da confiança pode ser utilizado para limitar situações não alcançadas pela vedação de irretroatividade das leis - como se dá no caso de leis retrospectivas, que atingiriam meras expectativas, e não propriamente direitos adquiridos -, no Brasil o mesmo tipo de vácuo normativo dá lugar à aplicação do princípio da segurança jurídica e da proteção da confiança.

Por essa razão, desenvolveu-se uma vasta doutrina, sobretudo nos campos do direito administrativo e do direito tributário, que defende essa dimensão subjetiva da segurança jurídica como limites à atuação estatal, para alcançar direitos ou expectativas não protegidos expressamente por tais garantias. ${ }^{25}$

A jurisprudência brasileira, todavia, ainda é tímida em usar o princípio da proteção da confiança e, quando o faz, emprega outros termos, como boa-fé ou a própria segurança jurídica. Muitos dos julgados reconhecem o princípio da proteção da confiança implicitamente, sem, contudo, reconhecer como tal. Pode-se citar o RE 370682/SC, em que o Ministro Ricardo Lewandowski assim se pronunciou em seu voto:

(...) Isso, sobretudo, em respeito ao princípio da segurança jurídica que, no dizer de Celso Antonio Bandeira de Mello, tem por escopo 'evitar alterações surpreendentes que instabilizem a situação dos administrados', bem como 'minorar os efeitos traumáticos que resultam de novas disposições jurídicas que alcançaram situações em curso'. (...) (BRASIL, 2007).

Com efeito, no MS 24448/DF, o Supremo Tribunal Federal entendeu que o princípio da segurança jurídica seria uma "projeção objetiva do princípio da dignidade da pessoa humana e elemento conceitual do Estado de Direito" (BRASIL, 2007, p. 146).

Na dimensão subjetiva da segurança jurídica - a proteção da confiança -, o princípio tem sido utilizado pelo Supremo Tribunal Federal em duas questões principais: impossibilidade de revogação e anulação de atos administrativos que gerem direitos aos

25 Dentre as quais, citam-se: Ferreira (p. 191-209); Aranha (1997, p. 12); Couto e Silva (1987, p. 46); Idem (2005); Meirelles (2008, p. 99-101); Mello (2009, p. 87); Di Pietro (2009, p. 87-88). 
seus beneficiários com o decurso do tempo e a impossibilidade de demissão de servidores contratados irregularmente, mas por atos aparentemente legítimos (quando controverso a admissão de servidores por concurso publico). (BRASIL, 2006b, p. 18).

Também no MS 26782/DF há referência expressa no acórdão de relatoria do Ministro Cesar Peluso sobre o princípio da confiança:

Tais ascensões funcionais são, pois, atos perfeitos, que já não podem ser alcançados pela revisão do Tribunal de Contas (...) por força da decadência, nem ademais, sem ofensa aos subprincípios da confiança e da segurança jurídicas (...) (BRASIL, 2008). (Grifo nosso).

No MS 26271 AgR/DF, o relator Ministro Celso de Mello adotou expressamente o princípio da proteção da confiança para cassar acórdão do Tribunal de Contas que mandava desconstituir a incorporação na pensão de um valor determinado, que havia sido concedido e vinha sendo pago há 13 anos. ${ }^{26}$

Não há, contudo, diversamente do que ocorre com o Tribunal Constitucional de Portugal, uma densificação pelo Supremo Tribunal Federal, de um critério de aplicação do princípio da proteção da confiança.

A despeito das cada vez mais constantes referências ao termo pelo Supremo Tribunal Federal, há mais um emprego retórico que técnico em sua jurisprudência. Contraditoriamente, o emprego da segurança jurídica pelo Supremo Tribunal Federal tem gerado insegurança jurídica.

6. A limitação do poder constituinte derivado pelo princípio da proteção da confiança

Em Portugal, o art. 288 da Constituição prevê os limites materiais de revisão, afirmando expressamente que as leis de revisão (equivalentes às emendas constitucionais brasileiras) devem respeitar, dentre outros, os direitos, liberdades e garantias dos cidadãos. Embora não haja menção aos direitos sociais, entende-se extensível tal vedação à dimensão desses direitos análoga a dos direitos, liberdades e garantias dos cidadãos. ${ }^{27}$

${ }_{26}$ Segundo Celso de Melo “Os postulados da segurança jurídica, da boa-fé objetiva e da proteção da confiança, enquanto expressões do Estado Democrático de Direito, mostram-se impregnados de elevado conteúdo ético, social e jurídico, projetando-se sobre as relações jurídicas, mesmo as de direito público, em ordem a viabilizar a incidência desses mesmos princípios sobre comportamentos de qualquer dos poderes ou órgãos do Estado (os Tribunais de Contas, inclusive), para que se preservem, desse modo, situações administrativas já consolidadas no passado". (BRASIL, 2013). (Grifo nosso).

27 Ou seja, a dimensão de exigibilidade do Poder Público de uma prestação garantida constitucionalmente (MORAIS, 2014, p. 471). Não se considera aqui o precedente da dupla revisão realizada em 1989, que teria, para alguns doutrinadores, tornado inócua a proteção prevista no art. 288 da CRP, por se tratar de uma verdadeira "fraude" constitucional legitimada social e politicamente, mediante acordo político prévio ditado por interesses econômicos que se impuseram sobre os "limites" jurídicos. A dupla revisão é um dos maiores 
Canotilho, v.g., parece se aproximar mais do entendimento de Schmitt, no sentido de que os limites implícitos de revisão resguardariam a identidade e continuidade da ordem constitucional, não aspectos pontuais. (CANOTILHO, 2003, p. 1.065).

De qualquer modo, se mesmo as cláusulas materiais expressas não foram observadas durante a revisão constitucional de 1989, admitir a limitação do Poder de Revisão em Portugal por um princípio implícito como a proteção da confiança é algo que se mostra possível em teoria, mas não no plano fático, especialmente diante de crises ou de necessidades históricas, como se deu no caso de necessidade de alteração da estrutura de sua Constituição para ingresso na União Europeia.

No Brasil, contudo, a eventual violação de princípios constitucionais pelo Poder Constituinte derivado é mais recorrente, o que se deve, especialmente, a duas ordens de fatores: a proliferação de emendas constitucionais que aqui se verifica, as quais são muitas vezes empregadas para contornar limitações ao legislador ordinário, e a forte densificação constitucional de alguns direitos sociais, como se dá com o direito previdenciário.

Em consequência, qualquer alteração pretendida nas regras de aposentadoria no Brasil deve ser objeto de emenda constitucional. Embora o órgão investido da função de Poder Constituinte derivado seja o mesmo órgão investido da função legislativa, o rito para aprovação de uma emenda constitucional é mais oneroso que o rito para aprovação de uma lei (ordinária ou complementar).

Nesse cenário, surge o problema de limitação do Poder Constituinte derivado pelos princípios implícitos, especialmente o da segurança jurídica, que é potencialmente afetado por grande parte das alterações constitucionais. (FERREIRA FILHO, 2007, p. 186).

No julgamento da ADI n. 3.128/DF, a maioria dos Ministros do STF "contornou" o problema da existência de princípios implícitos em face de emendas, reconhecendo a natureza tributária da contribuição dos inativos e sua constitucionalidade de acordo com os princípios tributários. De qualquer modo, a questão também foi analisada por alguns Ministros. ${ }^{28}$

exemplos recentes de que quando superestrutura jurídica e infraestrutura econômica entram em contradição insuperável, esta irrompe em antagonismo, o qual geral inevitavelmente uma necessidade de ruptura da ordem jurídica, seja por revolução, seja por uma fraude lógica que a preserve. Sobre as críticas jurídicas à dupla revisão, especialmente a de que o raciocínio da dupla revisão levaria a uma regressão ao infinito. (FAVOREU, 2002, p. 108).

28 No mesmo processo, o Ministro Nelson Jobim, que presidia o julgamento, preferiu ignorar a distinção entre Poder Constituinte Originário e Derivado, alegando que a Constituição de 1988 é no fundo fruto do Poder constituinte derivado, mas não tirou daí qualquer conclusão útil. O primeiro Ministro a analisar o caso sob a ótica da segurança jurídica foi Eros Grau. Uma primeira análise proveitosa foi a de que não há violação ao art. $60, \S 4^{\circ}$, porque a emenda não aboliu o direito adquirido, apenas poderia tê-lo violado, o que são coisas 
O tema é, de fato, complexo. Como poder subordinado, o poder constituinte derivado encontra seus limites de atuação em poder que lhe é superior, no caso, o poder constituinte soberano. A descrição desses limites, porém, encontra-se expressa na Constituição ou implícita, nos casos em que a própria estrutura constitucional não pode ser atingida. (SCHMITT, 1996, p. 118).

No caso, não está em discussão a abolição de cláusula pétrea. Não se pretende, $v . g$., abolir a previsão constitucional de respeito ao direito adquirido, ao contrário do que alegaram os demandantes da ADI 3128/DF. O que há é a inobservância de uma Emenda à Constituição do direito adquirido ou da proteção da confiança.

De fato, dispõe o inciso XXXVI do art. $5^{\circ}$ da Constituição de 1988: "XXXVI - a lei não prejudicará o direito adquirido, o ato jurídico perfeito e a coisa julgada". (Grifo nosso). Em primeiro lugar, a previsão constitucional é clara no sentido de que apenas a lei, não as normas constitucionais, devem respeitar o direito adquirido. A discussão em torno da acepção do termo lei pode ser resolvida, ainda, em sede de interpretação sistemática. É que as limitações ao Poder Constituinte derivado se encontram previstas no art. 60 , § $4^{\text {o }}$ IV, da Constituição de 1988. Assim, a proteção do direito adquirido é uma limitação às leis retroativas, não às emendas retroativas. Poder Constituinte Derivado e legislador apresentam uma relação de hierarquia natural, que decorre da própria legitimidade assegurada pelo procedimento diverso de sua atuação. Assim, o legislador se encontra limitado pelo princípio do direito adquirido, mas o Poder Constituinte não se encontra limitado pelo princípio, mas impedido de eliminar tal princípio vinculante da atividade legislativa. ${ }^{29}$

Essa era a jurisprudência dominante do Supremo Tribunal Federal, para o qual inexiste direito adquirido contra texto constitucional, quer produto do Poder Constituinte originário, quer produto do Poder Constituinte derivado. (BRASIL, 2002, p. 58).

Contra esse entendimento se posiciona parte da doutrina. José Afonso da Silva, e.g., entende que admitir que uma emenda constitucional afete direitos adquiridos seria uma "fraude à Constituição", na medida em que a proteção do direito estaria esvaziada na medida em que sua concretização - que é o fim da proteção - estaria desprotegida. (SILVA, 2002, p. 233).

Tal argumento, contudo, erra ao equiparar o Poder Constituinte derivado ao poder legislativo e ao desconsiderar que o direito adquirido é, antes de tudo, um princípio, que deverá ser sempre objeto de ponderação. A vinculação expressa ou implícita à sua

distintas.

29 Nesse sentido Bastos e Martins (1988, p. 191) e Machado (1995, p. 21-22). 
observância é dirigida apenas ao legislador, pois assim tencionou o Poder Constituinte originário.

Assim, parece acertada a orientação do Supremo Tribunal Federal em considerar que o Poder Constituinte derivado não está vinculado à proteção do direito adquirido. O mesmo não se pode dizer em relação ao princípio da proteção da confiança, por duas razões. Em primeiro lugar, porque a proteção da confiança, ao tutelar as legítimas expectativas que os cidadãos ostentam na estabilidade de ordem jurídica, projeta-se inclusive - sobre a própria estabilidade constitucional, o que não pode afastar sua aplicação mesmo nas revisões e alterações constitucionais pelo Poder Constituinte derivado.

Ademais disso, a aplicação do princípio da proteção da confiança, especialmente se forem considerados os critérios propostos pelo Tribunal Constitucional português, envolve a análise da razoabilidade da medida, bem como ponderações envolvendo o interesse público e as legítimas expectativas dos particulares. Tal qual a aplicação da regra da proporcionalidade, portanto, a aplicação da proteção da confiança ao caso de reformas, como a previdenciária, permitem uma correta avaliação da constitucionalidade da alteração na norma de direito social, cuja aferição pode ser meramente quantitativa, não qualitativa.

Vale dizer, em alguns casos, a aplicação do princípio da proteção da confiança a uma mudança nos critérios de aposentadoria pelo Poder Constituinte derivado poderá ser considerada inconstitucional pelo exagero na modificação pretendida, se desacompanhada de números que a justifiquem de forma incontrovertida e se vislumbrarem alternativas que violem com menos intensidade as expectativas criadas pelo Estado na manutenção de sua ordem jurídica.

Conclusão

O princípio da proteção da confiança, dimensão subjetiva do princípio da segurança jurídica, embora seja deduzido, tal qual este, histórico-conceitualmente da noção de Estado de Direito, não pode ser universalizável para cada sistema jurídicoconstitucional, em virtude das diversas opções hermenêuticas adotadas e do próprio grau de proteção constitucional à irretroatividade dos atos dos poderes constituídos.

Nada obstante, é possível apreender, da densificação de princípios abertos promovida no direito comparado, elementos que podem ser, se não transpostos, adaptados a outra ordem jurídica.

Com efeito, a diversidade, nos diversos ordenamentos jurídicos, como a segurança jurídica se manifesta no direito posto e no direito pressuposto, requer uma análise particular, sendo possível inferir limites e conteúdos materiais desse princípio apenas em cada plano intrassistêmico, como no caso dos direitos sociais. 
Como o critério de aferição de proteção à segurança jurídica em cada ordenamento se dá pelo grau de retroatividade normativa constitucionalmente permitido, quanto maior for esse grau, maior será a possibilidade de afetação da confiança dos indivíduos na estabilidade da ordem jurídica.

Daí decorre, portanto, as construções jurisprudenciais e doutrinárias que buscam limitar o legislador à afetação dessa confiança, a dimensão subjetiva do princípio da segurança jurídica.

A aplicação de um paradigma prático similar em ambos os países - o julgamento de reformas previdenciárias em contextos de crise econômico-financeira que afetaram direitos em formação e direitos adquiridos - permite comparar o emprego da tutela da confiança em ambos os sistemas.

Nesse sentido, o pioneiro desenvolvimento do princípio da proteção da confiança em Portugal, especialmente formulado pelo Tribunal Constitucional, com a indicação de critérios para sua aplicação aos casos concretos, deve ser ao menos considerado pela doutrina e jurisprudência brasileira, uma vez que nas próprias decisões judiciais costuma-se fazer referências ao princípio da proteção da confiança, sem, contudo, utilizar qualquer critério na sua aplicação.

No Brasil, a aplicação do princípio da proteção da confiança é ainda tímida e tem sido invocada para limitar a atividade administrativa, muitas vezes aplicada sob o nome de boa-fé ou mesmo de segurança jurídica. Em face do legislador, o princípio já foi invocado pelo Supremo Tribunal Federal, em decisões recentes, mas ainda não ocorreu sua aplicação isolada para a tutela de direitos em formação, no caso de retroatividade inautêntica, tampouco ao conflito entre o princípio do direito adquirido e outros princípios, dentre os quais o próprio princípio da solidariedade intergeracional e a reserva do financeiramente possível.

No caso de limitação ao Poder Constituinte derivado, embora se possa concordar com o posicionamento do Supremo Tribunal Federal, no sentido de que aquele não está vinculado ao princípio do direito adquirido, pela mesma natureza dessa cláusula, há que se entender que tal limitação existe em face do princípio da proteção da confiança, dada sua relação intrínseca com o princípio estruturante do Estado de Direito e igualmente em virtude de seu conteúdo, consistente na expectativa de estabilidade da ordem jurídica em sua totalidade, o que não afasta a ordem constitucional. Assim, pode-se afirmar que a violação do princípio do direito adquirido deverá ser objeto de ponderação segundo critérios lógicos que permitam asseverar a ocorrência de violação ao princípio da proteção da confiança, hipótese que permitirá a declaração de inconstitucionalidade da reforma ou supressão proposta.

Para todas essas situações, portanto, não alcançadas pelo princípio do direito adquirido, tem lugar a aplicação do princípio da proteção da confiança, hipótese em 
que o Poder Judiciário brasileiro deverá, a exemplo do que fez o Tribunal Constitucional português, declinar critérios lógico-racionais para sua aplicação, de modo a evitar, contraditoriamente, que a aplicação do princípio da segurança jurídica se converta em mais uma fonte de insegurança jurídica.

São Paulo, maio de 2017.

\section{Referências}

ALEXANDRINO, José de Melo. Direitos fundamentais: introdução geral. Parede: Principia, 2007. . Jurisprudência da crise. Das questões prévias às perplexidades. In: RIBEIRO, Gonçalo de Almeida; COUTINHO, Luís Pereira (Org.). O tribunal constitucional e a crise. Ensaios críticos. Coimbra: Almedina, 2014. p. 49-68.

AMARAL, Maria Lúcia. A forma da republica: uma introdução ao estudo do direito constitucional. Coimbra: Coimbra Editora, 2005.

ARANHA, Márcio Iorio. Segurança jurídica stricto sensu e legalidade dos atos administrativos. Convalidação do ato nulo pela imputação do valor de segurança jurídica em concreto à junção da boa-fé e do lapso temporal. Revista de Informação Legislativa, Brasília, v. 34, n. 134, p. 59-73, abr./ jun. 1997.

ARAÚJO, Valter Shuenquener de. O princípio da proteção da confiança: uma nova forma de tutela do cidadão diante do Estado. Niterói, RJ: Impetus, 2009.

ÁVILA, Humberto Bergmann. "Neoconstitucionalismo": entre a "ciência do direito" e o "direito da ciência". Revista Eletrônica de Direito do Estado, Salvador, n. 17, p. 1-19, jan./fev./mar. 2009. Disponível em: <http://www.direitodoestado.com/revista/rede-17-janeiro-2009-humberto\%20 avila.pdf>. Acesso em: 4 abr. 2017.

. Segurança jurídica: entre permanência, mudança e realização no direito tributário. São Paulo: Malheiros, 2011.

. Sistema constitucional tributário. São Paulo: Saraiva, 2005.

BARROS, Sérgio Resende de. A reforma da previdência e os direitos adquiridos dos servidores. In: CICLO DE SEMINÁRIOS, 1., jun. de 2003, São Paulo. (Texto básico da palestra "A reforma da Previdência Social no Congresso Nacional", no dia 2 de junho de 2003, no, realizado no Auditório Franco Montoro, em São Paulo, SP., sob o patrocínio da Assembleia Legislativa do Estado de São Paulo). Disponível em: <http://www.srbarros.com.br/pt/a-reforma-da-previdencia-e-os-direitosadquiridos-dos-servidores.cont>. Acesso em: 15 maio 2016.

. Contribuição dialética para o constitucionalismo. Campinas, SP: Millennium, 2007. 
BASTOS, Celso Seixas Ribeiro; MARTINS, Ives Gandra. Comentários à constituição do Brasil: promulgada em 5 de outubro de 1988. São Paulo: Saraiva, 1988. v. 2.

BEVILAQUA, Clóvis. Soluções praticas de direito: (pareceres). Rio de Janeiro: Corrêa Bastos, 1923. v. 1.

BRASIL. Assembléia nacional constituinte (atas de comissões). Anais da Assembleia Nacional Constituinte (1988). Brasília, DF. Disponível em: <http://www.senado.gov.br/publicacoes/anais/ constituinte/sistema.pdf>. Acesso em: 15 mar. 2017.

BYRD, B. Sharon; HRUSCHKA, Joachim. Kant's doctrine of right: a commentary. Cambridge, New York, Melbourne, Madrid, Cape Town, Singapore, São Paulo, Delhi, Dubai, Tokyo: Cambridge University Press, 2010.

CALMES, Sylvia. Du principe de protection de la confiance légitime en droits allemand, communautaire et français. Paris: Dalloz, 2001. (Nouvelle bibliothèque de thèses).

CANOTILHO, José Joaquim Gomes. Direito constitucional e teoria da constituição. 7. ed. Coimbra: Almedina, 2003.

CANOTILHO, José Joaquim Gomes; MOREIRA, Vital. Constituição da república portuguesa. Anotada. 4. ed. Coimbra: Coimbra Editora, 2007. 2 t.

COUTINHO, Luís Pedro Dias Pereira. A autoridade moral da constituição - da fundamentação da validade do direito constitucional. Coimbra: Coimbra Editora, 2009.

DERBLI, Felipe. A aplicabilidade do princípio da proibição de retrocesso social no direito brasileiro. In: SARMENTO, Daniel; SOUZA NETO, Cláudio Pereira de (Coord.). Direitos Sociais: fundamentos, judicialização e direitos sociais em espécie. Rio de Janeiro: Lúmen Juris, 2008. p. 345 .

DI PIETRO, Maria Sylvia Zanella. Direito administrativo. 22. ed. São Paulo: Atlas, 2009.

FAVOREU, Louis et al. Droit constitutionnel. 5. ed. Paris: Dalloz, 2002.

FERREIRA FILHO, Manoel Gonçalves. Estado de direito e constituição. São Paulo: Saraiva, 1988. . O poder constituinte. 5. ed. rev. São Paulo: Saraiva, 2007.

. Principios fundamentais do direito constitucional. Saraiva: São Paulo, 2009.

FERREIRA, Sergio de Andréa. O Princípio da segurança jurídica em face das reformas constitucionais. Revista Forense, Rio de Janeiro, v. 92, n. 334, p. 191-209, abr./jun. 1996.

FLEITAS DE LÉON, Luis. A propósito del concepto de "estado de derecho": un estudio y una propuesta para volver a su matriz genética. Revista de Derecho. Universidad de Montevideo, Montevideo, ano X, n. 20, p. 23-40, 2011. 
FRANÇA, Rubens Limongi. A irretroatividade das leis e o direito adquirido. 5. ed. rev. e atual. do Direito intertemporal brasileiro e acrescentada do Projeto de Lei de Aplicações das Normas Jurídicas, de 1995. São Paulo: Saraiva, 1998.

FREITAS, Tiago Fidalgo de. O princípio da proibição de retrocesso social. In: MIRANDA, Jorge. (Coord.). Estudos em homenagem ao Professor Doutor Marcello Caetano: no centenário do seu nascimento. Lisboa: FADUL, 2006. p. 783-850. 2 v.

GARCIA MANRIQUE, Ricardo. El valor de la seguridad jurídica. Madrid: Iustel, 2012.

GOZZI, Gustavo. Kant: la concezione della democrazia sul fondamento dei diritti. In: BOLOGNESI, Dante; MATTARELLI, Sauro (a cura di). L'Illuminismo e i suoi critici. Milano: Franco Angeli, 2011. p. 85-107.

HÄBERLE, Peter. Hermenêutica constitucional: a sociedade aberta dos intérpretes da constituição: contribuição para a interpretação pluralista e "procedimental" da constituição. Trad. Gilmar Ferreira Mendes. Porto Alegre: Sergio Antônio Fabris, 2002.

HAYEK, Friedrich August von. Os fundamentos da liberdade. Tradução de Anna Maria Capovilla e José Ítalo Stelle. São Paulo: Visão, 1983. (Título original: The constitution of liberty).

KELSEN, Hans. Teoria pura do direito. 6. ed. Trad. João Baptista Machado. São Paulo: Martins Fontes, 1999.

LOCKE, John. Two treatises of government. London: Thomas Hollis, 1689. 2 v. (a versão fac-símilar do original está disponível em: <http://oll.libertyfund.org/titles/222>. Acesso em: 1 jan. 2017.

LUCAS VERDÚ, Pablo. La lucha por el estado de derecho. Bolonia: Real Colegio de España, 1975.

LUHMANN, Niklas. Sociologia do direito. Trad. Gustavo Bayer. Rio de Janeiro: Tempo Brasileiro, 1983. v. 1.

MACHADO, Hugo de Brito. Direito adquirido e coisa julgada como garantias constitucionais. Revista dos Tribunais, São Paulo, v. 84, n. 714, p. 21-22, abr. 1995.

MAURER, Hartmut. Elementos de direito administrativo alemão. Trad. Luís Afonso Heck. Porto Alegre: Sérgio Antonio Fabris Editor, 2001.

MEDAUAR, Odete. Segurança jurídica e confiança legítima. In: ÁVILA, Humberto (Org.). Fundamentos do Estado de Direito. Estudos em homenagem ao Professor Almiro do Couto e Silva. São Paulo: Malheiros Editores, 2005. p. 114-119.

MEIRELLES, Hely Lopes. Direito administrativo brasileiro. 34. ed. atualizada até a Emenda Constitucional 53, de 19.12.2006, e Lei 11.448, de 15.1.2007 por Eurico de Andrade Azevedo, Délcio Balestero Aleixo e José Emmanuel Burle Filho. São Paulo: Malheiros, 2008. 
MELLO, Celso Antônio Bandeira de. Curso de direito administrativo. 26. ed., rev. e atualizada até a Emenda Constitucional 56, de 20.12.2007. São Paulo: Malheiros, 2009.

MIRANDA, Jorge. Manual de direito constitucional. Direitos Fundamentais. 5. ed. Coimbra: Coimbra Editora, 2012. t. 4.

MIRANDA, Jorge; MEDEIROS, Rui. Constituição portuguesa anotada. 2. ed. Coimbra: Wolters Kluwer / Coimbra Editora, 2010. t. 1.

MONTESQUIEU, Charles de Secondat. Baron de la Brède. De l'esprit des lois. Introd. notas e variantes por Gonzague Truc. Paris: Garnier Frères, 1949. 2 t.

MORAIS, Carlos Blanco de. Segurança jurídica e justiça constitucional. Revista da Faculdade de Direito de Lisboa, Lisboa, v. 41, n. 2, p. 619-30, 2000.

. Algumas reflexões sobre o valor jurídico de normas parasitárias presentes em leis reforçadas pelo procedimento. In: MIRANDA, Jorge. Nos 25 anos da Constituição da República Portuguesa de 1976. Evolução constitucional e perspectivas futuras. Lisboa: AAFDL, 2001. p. 393-469.

Curso de direito constitucional: teoria da constituição em tempo de crise do Estado social. Coimbra: Coimbra Editora, 2014. v. 2. t. 2.

NOVAIS, Jorge Reis. As restrições aos direitos fundamentais não expressamente autorizadas pela constituição. [Lisboa]: Coimbra, 2003.

. Contributo para uma teoria do estado de direito: do estado de direito liberal ao estado social e democrático de direito. Coimbra: Almedina, 2006.

. Os princípios constitucionais estruturantes da república portuguesa. Coimbra: Coimbra Editora, 2004.

OTERO, Paulo. Instituições políticas e constitucionais. Coimbra: Almedina, 2009. v. 1.

PINTO, Paulo Mota. A proteção da confiança na jurisprudência da crise. In: COUTINHO, Luís Pereira; RIBEIRO, Gonçalo de Almeida (Org.). O tribunal constitucional e a crise: ensaios críticos. Coimbra: Almedina, 2014. p. 133-185.

PRANEVIČIENĖ, Birutė; MIKALAUSKAITĖ-ŠOSTAKIENĖ, Kristina. Guarantee of principles of legitimate expectations, legal certainty and legal security in the territorial planning process. Jurisprudencija: Mokslo darbu žurnalas, Lithuania, v. 19, n. 2, p. 643-656, 2012. Disponível em: $<$ https://www.mruni.eu/upload/iblock/0e2/013 praneviciene mikalauskaite sostakiene.pdf $>$. Acesso em: 19 ago. 2016.

QUEIROZ, Cristina. O tribunal constitucional e os direitos sociais. Coimbra: Coimbra Editora, 2014.

RAMOS, Elival da Silva. A proteção dos direitos adquiridos no direito constitucional brasileiro. São Paulo: Saraiva, 2003. 
RÁO, Vicente. Ato jurídico. São Paulo: Max Limonad, 1961.

ROCHA JÚNIOR, Luis Clóvis Machado. A decisão sobre os efeitos do ato inconstitucional. Porto Alegre: Sergio Antônio Fabris, 2014.

RODRÍGUEZ-ARANA, Jaime. El principio general del derecho de confianza legítima. Ciencia Jurídica. Departamento de Derecho. División de Derecho Política y Gobierno, Universidad de Guanajuato, Año 1, n. 4, p. 59-70, 2013.

ROUSSEAU, Jean-Jacques. Du contrat social: ou principes du droit politique. Amsterdam: Marc Michel Rey, 1762. (a versão original digitalizada está disponível em: $<$ https://archive.org/details/ ducontratsoc00rous>. Acesso em: 1 maio 2016.

SANZ RUBIALES, Iñigo. El principio de confianza legítima, limitador del poder normativo comunitario. Revista de Derecho Comunitario Europeo, Centro de Estudios Políticos y Constitucionales, Madrid, v. 4, n. 7, p. 91-122, jan./jun. 2000.

SARLET, Ingo Wolfgang. Proibição de retrocesso, dignidade da pessoa humana e direitos sociais: manifestação de um constitucionalismo dirigente possível. Revista Eletrônica sobre a Reforma do Estado, Salvador, n. 15, set./out./nov. 2008. Disponível em: < http://www.direitodoestado.com/ revista/RERE-15-SETEMBRO-2008-INGO\%20SARLET.pdf>. Acesso em: 1 mar. 2017.

SCHMITT, Carl. Teoría de la constitución. Trad. Francisco Ayala. Madrid: Alianza Editorial, 1996.

SILVA, Almiro do Couto e. O princípio da segurança jurídica (proteção à confiança) no Direito Público Brasileiro e o Direito da Administração Pública de anular seus próprios atos administrativos: o prazo decadencial do art. 54 da Lei do Processo Administrativo da União (Lei n. 9.784/99). REDE - Revista Eletrônica de Direito do Estado, Salvador, Instituto de Direito Público da Bahia, n. 2, abr./maio/jun. 2005. Disponível em: <http://www.direitodoestado.com.br/artigo/almiro-do-coutoe-silva/o-principio-da-seguranca-juridica-protecao-a-confianca-no-direito-publico-brasileiro-e-odireito-da-administracao-publica-de-anular-seus-proprios-at>. Acesso em: 27 mar. 2017.

. Princípios da legalidade e da administração pública e da segurança jurídica no Estado de Direito contemporâneo. Revista de Direito Público, São Paulo, v. 20, n. 84, p. 46-63, out./dez., 1987.

SILVA, José Afonso da. Poder constituinte e poder popular: estudos sobre a Constituição. São Paulo: Malheiros, 2002.

STEIN, Torsten. A segurança jurídica na ordem legal da república federal da Alemanha. Cadernos Adenauer, Rio de Janeiro, v. 3 (Acesso à justiça e cidadania), 2000.

XAVIER, Alberto. Manual de direito fiscal. Lisboa: Almedina, 1974. v. 1.

ZIPPELIUS, Reinhold. Teoria geral do estado. Trad. Karin Praefke-Aires Coutinho. 3. ed. Lisboa: Fundação Calouste Gulbenkian, 1997. 


\section{Jurisprudência}

BRASIL. Supremo Tribunal Federal. Ação direta de inconstitucionalidade n. $1497 \mathrm{MC} / \mathrm{DF}$ - Distrito Federal. Relator: Ministro Marco Aurélio. Acórdãos, 9 out. 1996. DJ, 13 dez. 2002. Disponível em: $<$ http://www.stf.jus.br/portal/jurisprudencia/listarJurisprudencia.asp?s1=\%28ADI\%24\%2ESCLA $\% 2 \mathrm{E}+\mathrm{E}+1497 \% 2 \mathrm{ENUME} \% 2 \mathrm{E} \% 29+\mathrm{OU}+\% 28 \mathrm{ADI} \% 2 \mathrm{EACMS} \% 2 \mathrm{E}+\mathrm{ADJ} 2+1497 \% 2 \mathrm{EACMS} \% 2 \mathrm{E}$ $\% 29 \&$ base $=$ baseAcordaos\&url=http://tinyurl.com/bjuossf $>$.

BRASIL. Supremo Tribunal Federal. Ação direta de inconstitucionalidade n. 2242/DF - Distrito Federal. Relator: Ministro Moreira Alves. Acórdãos, 7 fev. 2001. DJ, 19 dez. 2001. Disponível em: $<$ http://www.stf.jus.br/portal/jurisprudencia/listarJurisprudencia.asp?s1=\%28ADI\%24\%2ESCLA $\% 2 \mathrm{E}+\mathrm{E}+2242 \% 2 \mathrm{ENUME} \% 2 \mathrm{E} \% 29+\mathrm{OU}+\% 28 \mathrm{ADI} \% 2 \mathrm{EACMS} \% 2 \mathrm{E}+\mathrm{ADJ} 2+2242 \% 2 \mathrm{EACMS} \% 2 \mathrm{E}$ $\% 29 \&$ base=baseAcordaos\&url=http://tinyurl.com/bbc77ut>.

BRASIL. Supremo Tribunal Federal. Ação direta de inconstitucionalidade n. 2666 ED/DF - Distrito Federal. Relatora: Ministra Ellen Gracie. Acórdãos, 3 out. 2002. DJ, 10 nov. 2006a. Disponível em: $<$ http://www.stf.jus.br/portal/jurisprudencia/listarJurisprudencia.asp?s1=\%28ADI\%24\%2ESCLA $\% 2 \mathrm{E}+\mathrm{E}+2666 \% 2 \mathrm{ENUME} \% 2 \mathrm{E} \% 29+\mathrm{OU}+\% 28 \mathrm{ADI} \% 2 \mathrm{EACMS} \% 2 \mathrm{E}+\mathrm{ADJ} 2+2666 \% 2 \mathrm{EACMS} \% 2 \mathrm{E}$ $\% 29 \&$ base=baseAcordaos\&url=http://tinyurl.com/b5ubnxr>.

BRASIL. Supremo Tribunal Federal. Ação direta de inconstitucionalidade n. 3128/DF - Distrito Federal. Relator: Ministro Cesar Peluso. Acórdãos, 18 ago. 2004. DJ, 18 fev. 2005. Disponível em: $<$ http://www.stf.jus.br/portal/jurisprudencia/listarJurisprudencia.asp?s1=\%28ADI\%24\%2ESCLA $\% 2 \mathrm{E}+\mathrm{E}+3128 \% 2 \mathrm{ENUME} \% 2 \mathrm{E} \% 29+\mathrm{OU}+\% 28 \mathrm{ADI} \% 2 \mathrm{EACMS} \% 2 \mathrm{E}+\mathrm{ADJ} 2+3128 \% 2 \mathrm{EACMS} \% 2 \mathrm{E}$ $\% 29 \&$ base=baseAcordaos\&url=http://tinyurl.com/a3lahc2>.

BRASIL. Supremo Tribunal Federal. Mandado de segurança n. 24927/RO. Relator: Ministro Cezar Peluso. Acórdãos, 28 set. 2005. DJ, 25 ago. 2006b. Disponível em: <http://www.stf.jus.br/portal/ jurisprudencia/listarJurisprudencia.asp?s1=\%28MS\%24\%2ESCLA $\% 2 \mathrm{E}+\mathrm{E}+24927 \% 2 \mathrm{ENUME} \% 2$ $\mathrm{E} \% 29+\mathrm{OU}+\% 28 \mathrm{MS} \% 2 \mathrm{EACMS} \% 2 \mathrm{E}+\mathrm{ADJ} 2+24927 \% 2 \mathrm{EACMS} \% 2 \mathrm{E} \% 29 \&$ base=baseAcordaos\&u $\mathrm{rl}=\mathrm{http}: / /$ tinyurl.com/bsgwcf9 $>$.

BRASIL. Supremo Tribunal Federal. Recurso extraordinário n. 370682/SC. Relator: Ministro Gilmar Mendes. Acórdãos, 25 jun. 2007. DJe, 17 nov. 2010. Disponível em: <http://www.stf.jus.br/ portal/jurisprudencia/listarJurisprudencia.asp?s1=\%28RE $\% 24 \% 2 \mathrm{ESCLA} \% 2 \mathrm{E}+\mathrm{E}+370682 \% 2 \mathrm{ENU}$ $\mathrm{ME} \% 2 \mathrm{E} \% 29+\mathrm{OU}+\% 28 \mathrm{RE} \% 2 \mathrm{EACMS} \% 2 \mathrm{E}+\mathrm{ADJ} 2+370682 \% 2 \mathrm{EACMS} \% 2 \mathrm{E} \% 29 \&$ base=baseAco rdaos\&url=http://tinyurl.com/ar5238k $>$.

BRASIL. Supremo Tribunal Federal. Mandado de segurança n. 24448/DF - Distrito Federal. Relator: Ministro Carlos Britto. Acórdãos, 27 set. 2007. DJ, 14 nov. 2007. Disponível em: <http:// www.stf.jus.br/portal/jurisprudencia/listarJurisprudencia.asp?s1=\%28MS\%24\%2ESCLA $\% 2 \mathrm{E}+\mathrm{E}+$ $24448 \% 2 \mathrm{ENUME} \% 2 \mathrm{E} \% 29+\mathrm{OU}+\% 28 \mathrm{MS} \% 2 \mathrm{EACMS} \% 2 \mathrm{E}+\mathrm{ADJ} 2+24448 \% 2 \mathrm{EACMS} \% 2 \mathrm{E} \% 29 \& \mathrm{~b}$ ase $=$ baseAcordaos\&url=http://tinyurl.com/ahjw337> . 
BRASIL. Supremo Tribunal Federal. Mandado de segurança n. 26782/DF - Distrito Federal. Relator: Ministro Cezar Peluso. Acórdãos, 17 dez. 2007. DJe, 22 fev. 2008. Disponível em: <http:// www.stf.jus.br/portal/jurisprudencia/listarJurisprudencia.asp?s1=\%28MS $\% 24 \% 2 \mathrm{ESCLA} \% 2 \mathrm{E}+\mathrm{E}+$ $26782 \% 2 \mathrm{ENUME} \% 2 \mathrm{E} \% 29+\mathrm{OU}+\% 28 \mathrm{MS} \% 2 \mathrm{EACMS} \% 2 \mathrm{E}+\mathrm{ADJ} 2+26782 \% 2 \mathrm{EACMS} \% 2 \mathrm{E} \% 29 \& \mathrm{~b}$ ase $=$ baseAcordaos\&url=http://tinyurl.com/bbpj8yx $>$.

BRASIL. Supremo Tribunal Federal. Mandado de segurança n. 26271 AgR/DF - Distrito Federal. Relator: Ministro Celso de Mello. Acórdãos, 4 dez. 2012. DJe, 28 maio. 2013. Disponível em: $<$ http://www.stf.jus.br/portal/jurisprudencia/listarJurisprudencia.asp?s1=\%28MS\%24\%2ESCLA\% $2 \mathrm{E}+\mathrm{E}+26271 \% 2 \mathrm{ENUME} \% 2 \mathrm{E} \% 29+\mathrm{OU}+\% 28 \mathrm{MS} \% 2 \mathrm{EACMS} \% 2 \mathrm{E}+\mathrm{ADJ} 2+26271 \% 2 \mathrm{EACMS} \% 2 \mathrm{E}$ $\% 29 \&$ base=baseAcordaos\&url=http://tinyurl.com/cwp5lcw $>$.

PORTUGAL. Tribunal Constitucional. Processo n. 94/1983. Relator: Conselheiro Martins da Fonseca. Acórdão n. 11/1983, Lisboa, 12 out. 1983a. Disponível em: <http:/www.tribunalconstitucional.pt/ tc/acordaos/19830011.html>.

PORTUGAL. Tribunal Constitucional. Processo n. 22/1983. Relator: Conselheiro Mário de Brito. Acórdão n. 20/1983, Lisboa, 16 nov. 1983b. Disponível em: <http://www.tribunalconstitucional.pt/ tc/acordaos/19830020.html>.

PORTUGAL. Tribunal Constitucional. Processo n. 309/1988. Relator: Conselheiro Sousa e Brito. Acórdão n. 287/1990, Lisboa, 30 out. 1990. <http://www.tribunalconstitucional.pt/tc/ acordaos/19900287.html>.

PORTUGAL. Tribunal Constitucional. Processos ns. 2/2013, 5/2013, 8/2013 e 11/2013. Relator: Conselheiro Carlos Fernandes Cadilha. Acórdão n. 187/2013, Lisboa, 5 abr. 2013a. Disponível em: $<$ http://www.tribunalconstitucional.pt/tc/acordaos/20130187.html>.

PORTUGAL. Tribunal Constitucional. Processo n. 772/2007. Relatora: Conselheira Maria Lúcia Amaral. Acórdão n. 128/2009, Lisboa, 27 maio 2009. Disponível em: <http://www. tribunalconstitucional.pt/tc/acordaos/20140575.html>.

PORTUGAL. Tribunal Constitucional. Processo n. 819/2014. Relator: Conselheiro Carlos Fernandes Cadilha. Acórdão n. 575/2014, Lisboa, 14 ago. 2014. Disponível em: <http://www. tribunalconstitucional.pt/tc/acordaos/20140575.html>.

PORTUGAL. Tribunal Constitucional. Processo n. 1260/2013. Relator: Conselheiro Lino Rodrigues Ribeiro. Acórdão n. 862/2013, Lisboa, 19 dez. 2013b. Disponível em: <http://www. tribunalconstitucional.pt/tc/acordaos/20130862.html>.

\section{Legislação}

BRASIL. Constituição (1988). Constituição da República Federativa do Brasil de 1988. Portal do Palácio do Planalto, Brasília, out. 1988. Disponível em: <http://www.planalto.gov.br/ccivil_03/ constituicao/constituicao.htm>. Acesso em: 15 maio 2017. 
PORTUGAL. Lei n. 4, de 16 de janeiro de 2007. Aprova as bases gerais do sistema de segurança social. Diário da República, Lisboa, 16 jan. 2007. $1^{\text {a }}$ série, n. 11, p. 345-356. Disponível em: $<$ https://dre.pt/application/file/522716>. 